\title{
Dissociation Pattern of Sodiated Amide Peptides as a Tool for De Novo Sequencing
}

Elodie Logerot, Christine Enjalbal*

IBMM, CNRS, ENSCM, University of Montpellier, 34095 Montpellier, France.

Table of Contents

Table S1: Unmodified C-terminus peptide sequences

Figure S1: MS/MS spectra of protonated and sodiated LAVGIAE- $\mathrm{NH}_{2}$ peptide recorded on the three different mass spectrometers

Figure S2: MS/MS spectrum of protonated APIAGFV-NH2 peptide recorded on Synapt G2-S mass spectrometer (Q-Tof)

Figure S3: MS/MS spectra of sodiated Asp- or Glu- containing peptides

Figure $\mathrm{S} 4: \mathrm{MS}^{\mathrm{n}}$ iterative experiments from $\left[\mathrm{b}_{6}+\mathrm{Na}+\mathrm{OH}\right]^{+}$ion of FPCEAFA- $\mathrm{NH}_{2}$ and FPCEAFA peptides recorded on AmaZon Speed mass spectrometer

Figure S5: MS/MS spectra of sodiated Ser-, Thr- or Tyr- containing peptides

Figure S6: $\left[b_{n-x}+\mathrm{Na}+\mathrm{OH}\right]^{+}$ion intensities issued from MS/MS experiments of Ser/Thr containing peptides based on Synapt-G2S data

Figure $\mathrm{S} 7: \mathrm{MS}^{\mathrm{n}}$ iterative experiments from $\left[\mathrm{b}_{6}+\mathrm{Na}+\mathrm{OH}\right]^{+}$ion of YFAVAIA- $\mathrm{NH}_{2}$ peptide recorded on AmaZon Speed mass spectrometer

Figure S8: MS/MS spectra of Arg- or His- ended and internal Arg- or His- containing peptides

Table S1: Unmodified C-terminus peptide sequences

\begin{tabular}{|c|l|c|c|}
\hline $\mathrm{N}^{\circ}$ & \multicolumn{1}{|c|}{ Sequence } & {$[\mathrm{M}+\mathrm{H}]^{+}$} & {$[\mathrm{M}+\mathrm{Na}]^{+}$} \\
\hline \multicolumn{4}{|c}{} \\
$2^{*}$ & APIAGFV & 674,3872 & 696,3691 \\
$6^{*}$ & FPCDAFA & 770,3178 & 792,2997 \\
$7^{*}$ & FPCEAFA & 784,3334 & 806,3153 \\
$15^{*}$ & AGVDNFG & 679,3046 & 701,2865 \\
$18^{*}$ & VYAGEVAH & 845,4152 & 867,3971 \\
$19^{*}$ & LAVAIAS & 644,3978 & 666,3797 \\
$22^{*}$ & LAVTAIA & 658,4134 & 680,3953 \\
$26^{*}$ & AFISVGPLAR & 1030,6044 & 680,3953 \\
$37^{*}$ & FPARVGI & 759,4512 & 781,4331 \\
\hline
\end{tabular}


Figure S1: MS/MS spectra of protonated and sodiated LAVGIAE-NH2 peptide recorded on different mass spectrometers

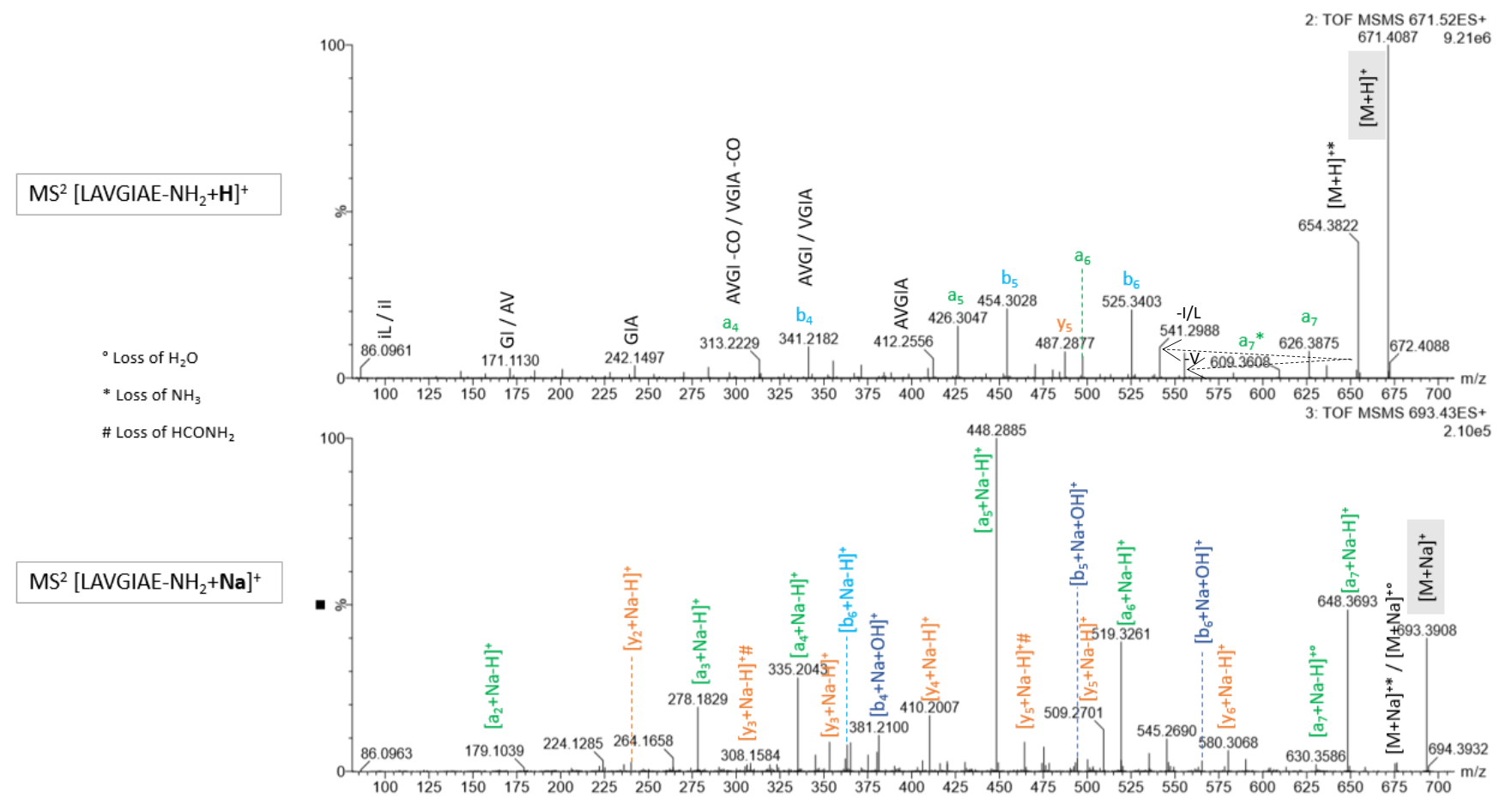

Figure S1a: MS/MS spectra recorded on Synapt G2-S mass spectrometer (Q-Tof)

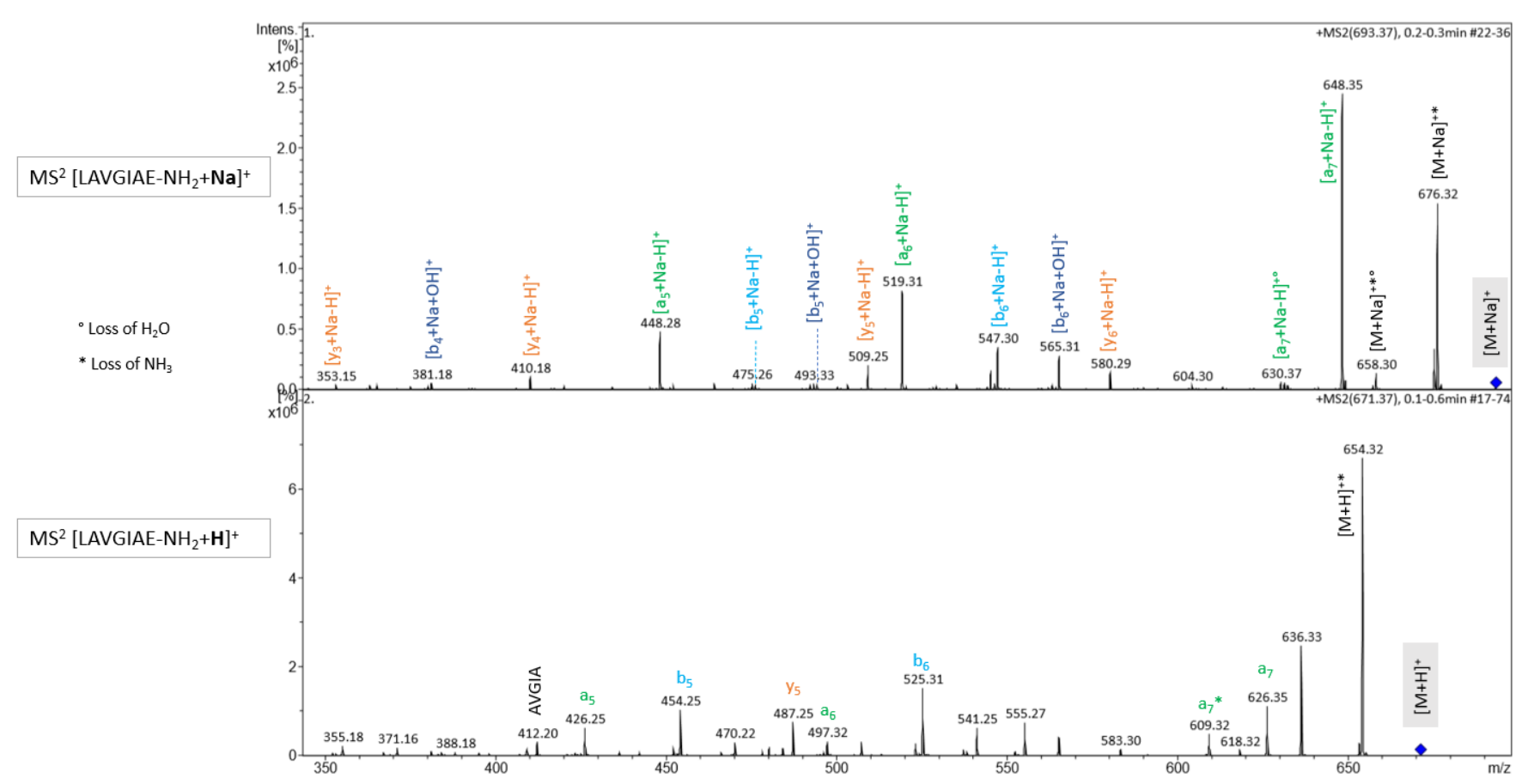

Figure S1b: MS/MS spectra recorded on AmaZon Speed mass spectrometer (Ion Trap) 


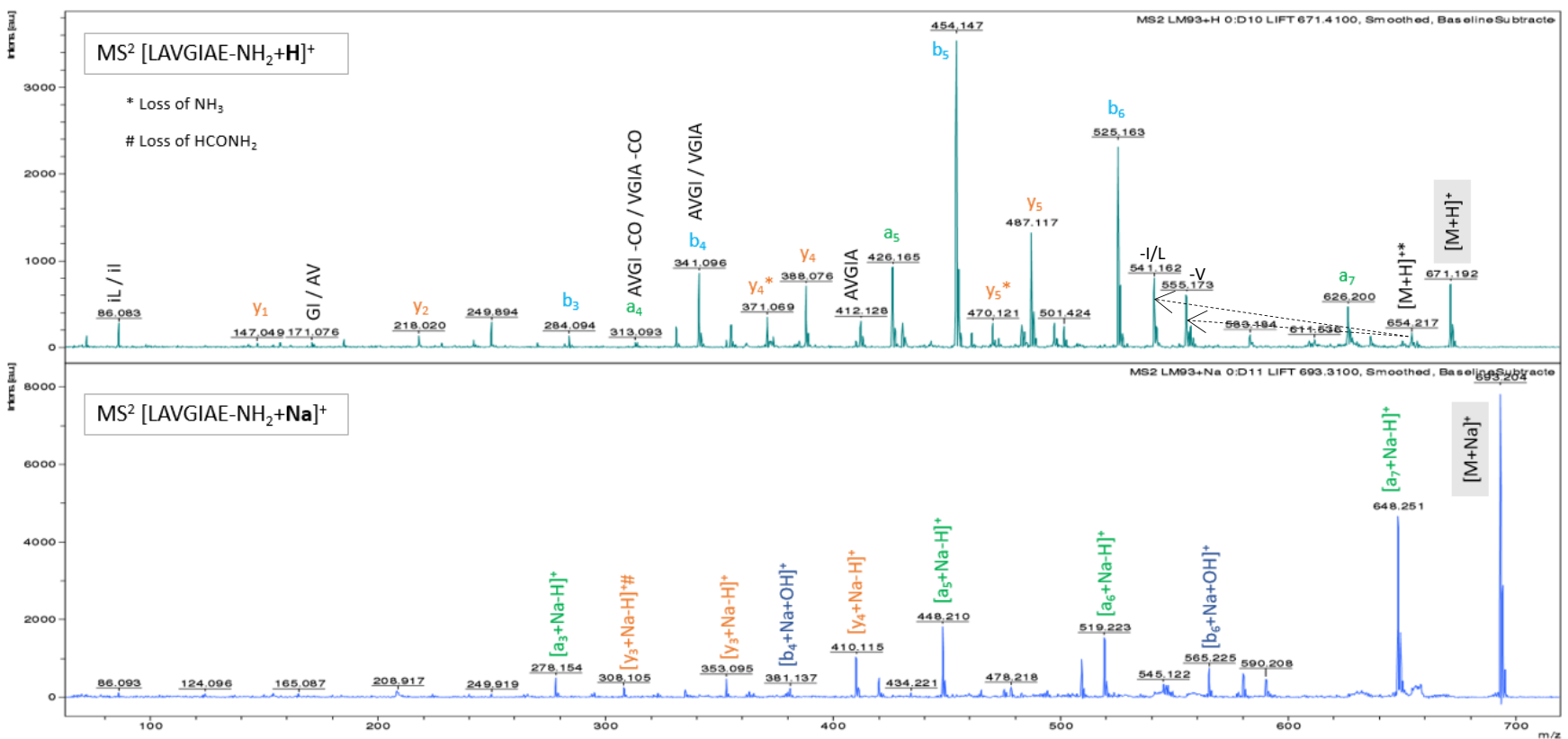

Figure S1c: MS/MS spectra recorded on Rapiflex mass spectrometer (Tof/Tof)

Figure S2: MS/MS spectrum of protonated APIAGFV-NH2 peptide recorded on Synapt G2-S mass spectrometer (Q-Tof)

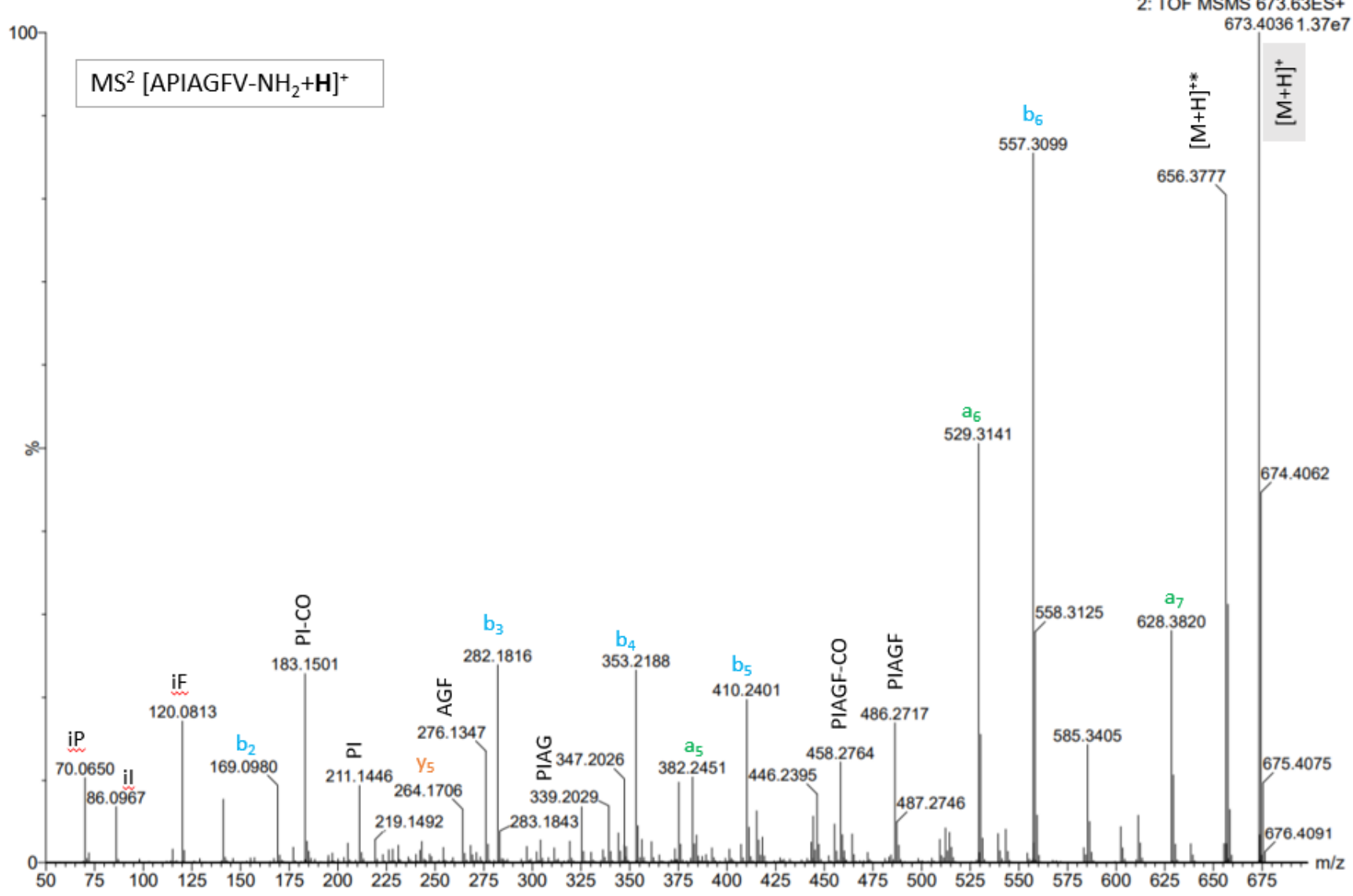


Figure S3: MS/MS spectra of Asp- or Glu- containing peptides

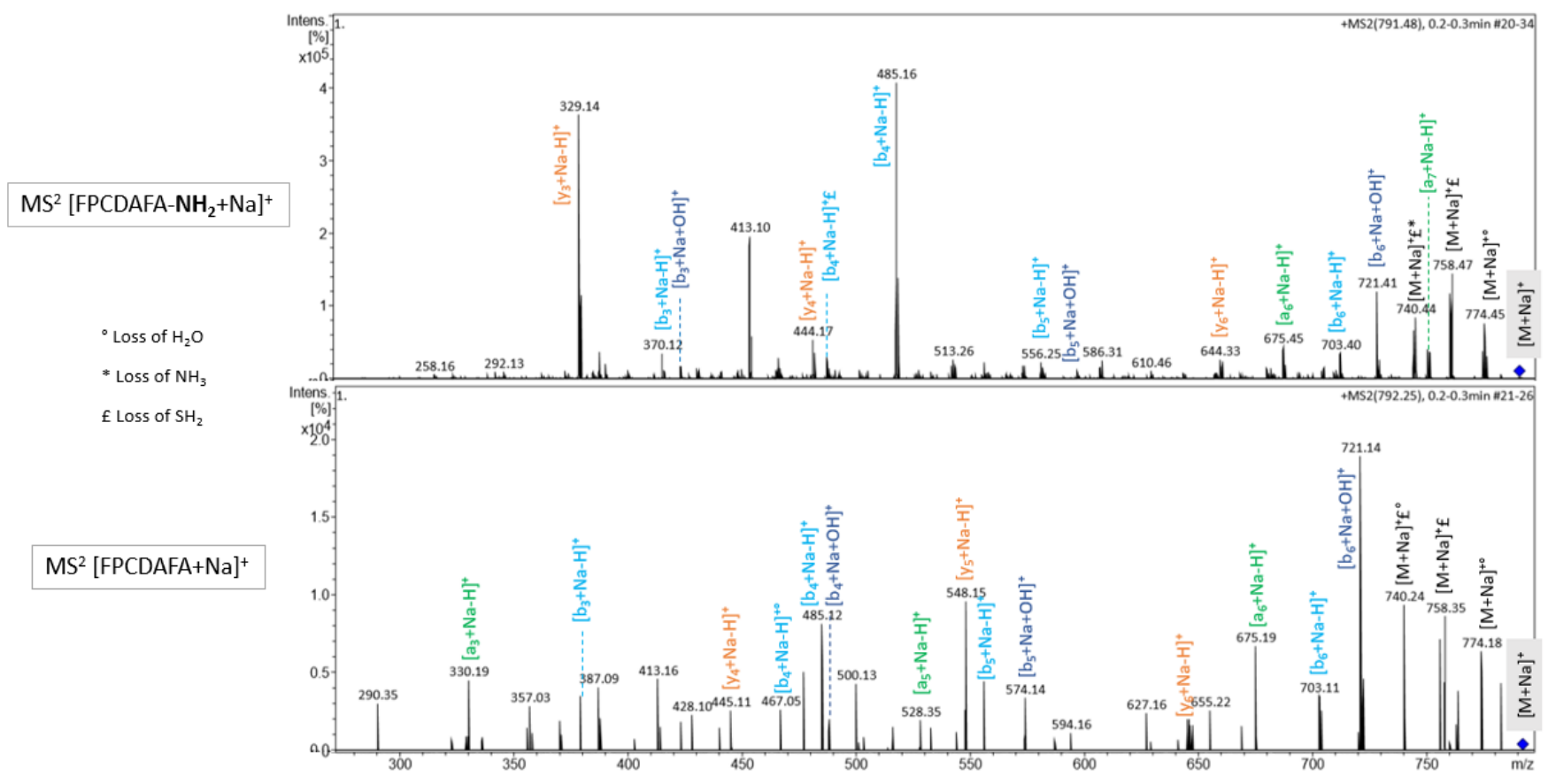

Figure S3a: MS/MS spectra of FPCDAFA- $\mathrm{NH}_{2}$ and FPCDAFA peptides ( $\mathrm{N}^{\circ} 6$ in Table 1) recorded on Amazon Speed mass spectrometer (Ion Trap)

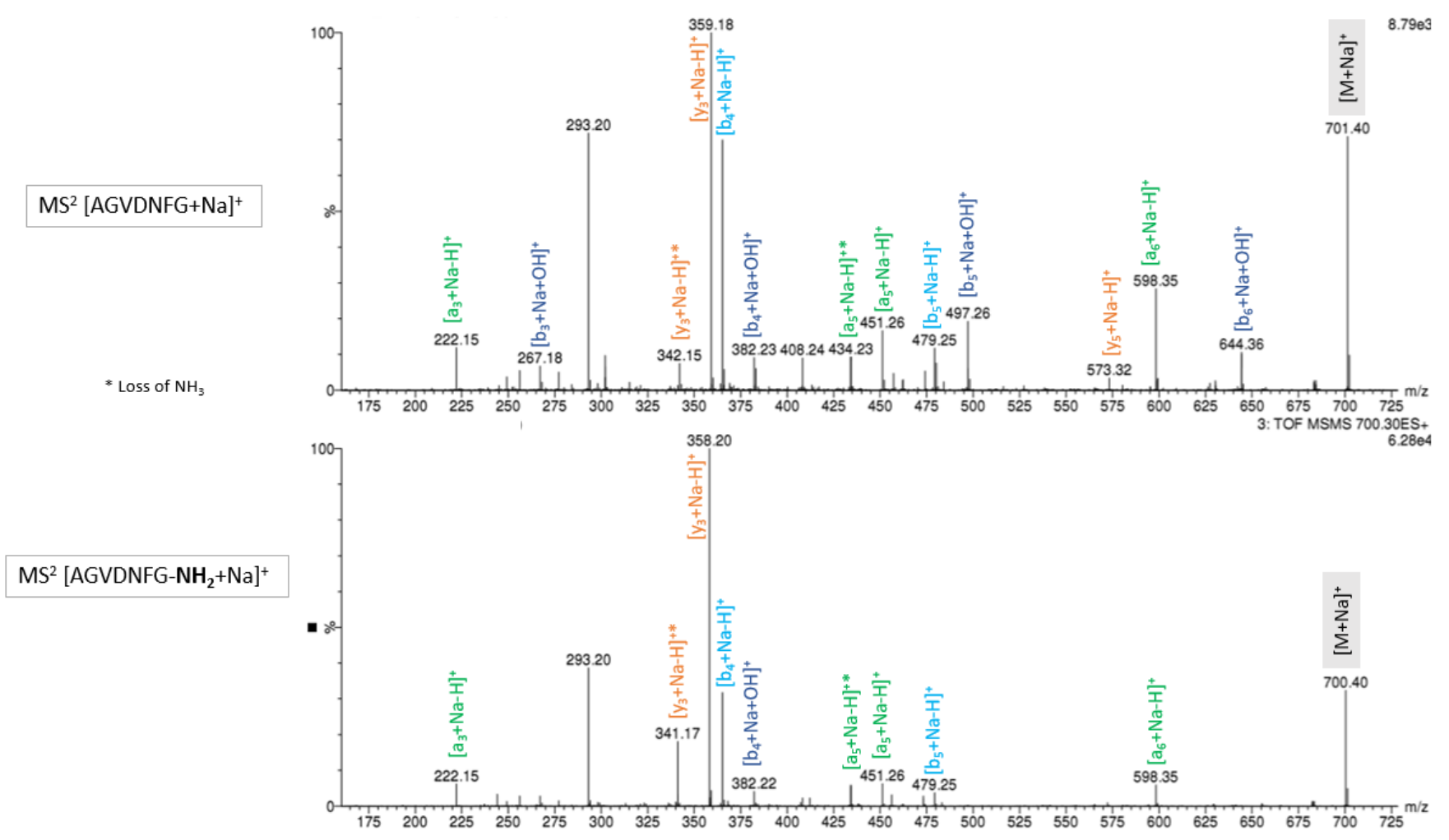

Figure S3b: MS/MS spectra of AGVDNF and AGVDNFG-NH $\mathrm{NH}_{2}$ peptides ( $\mathrm{N}^{\circ} 15$ in Table 1) recorded on Synapt G2-S mass spectrometer (QTof) 


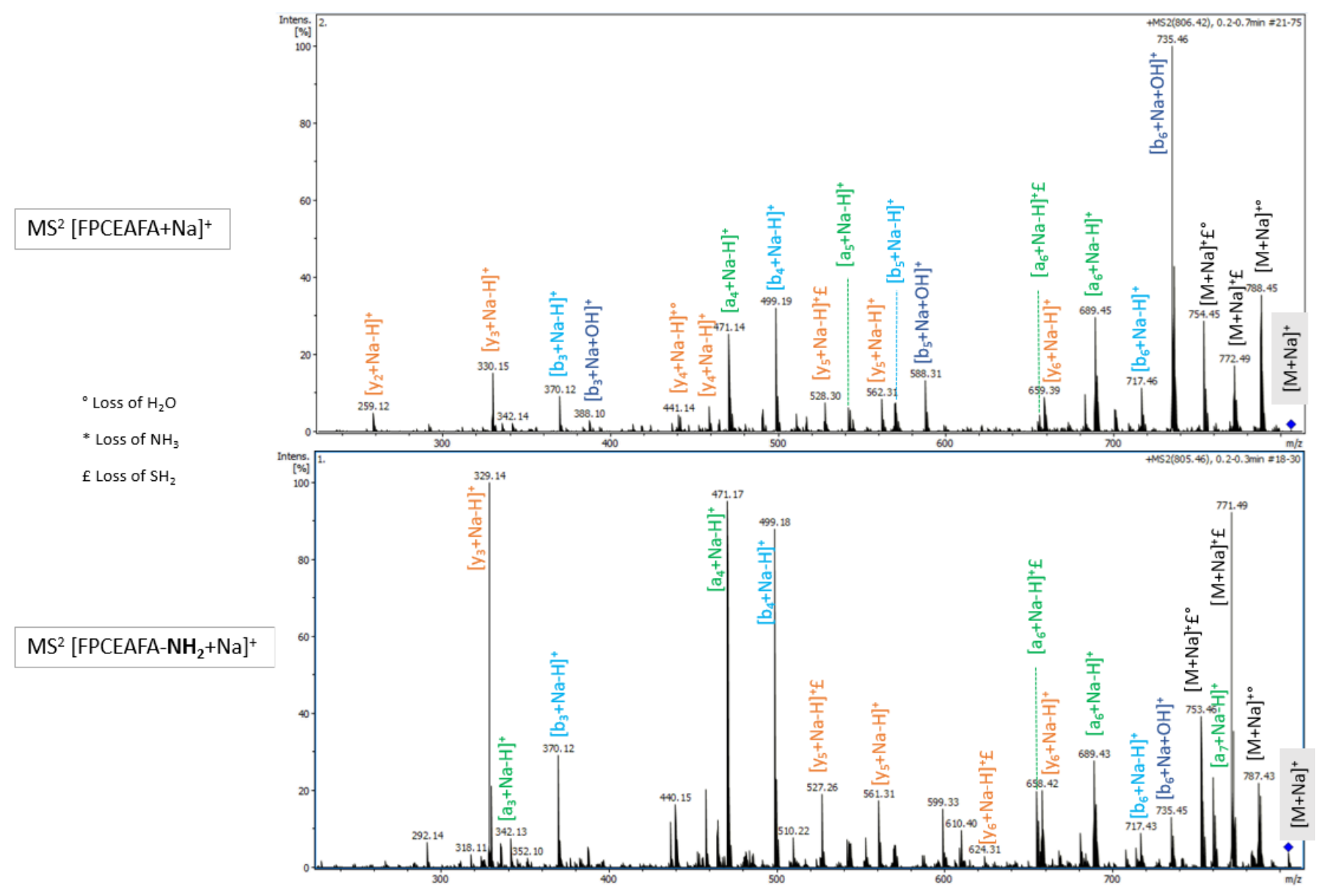

Figure S3c: MS/MS spectra of FPCEAFA-NH $\mathrm{NH}_{2}$ and FPCEAFA peptides ( $\mathrm{N}^{\circ} 7$ in Table 1) recorded on Amazon Speed mass spectrometer (Ion Trap)

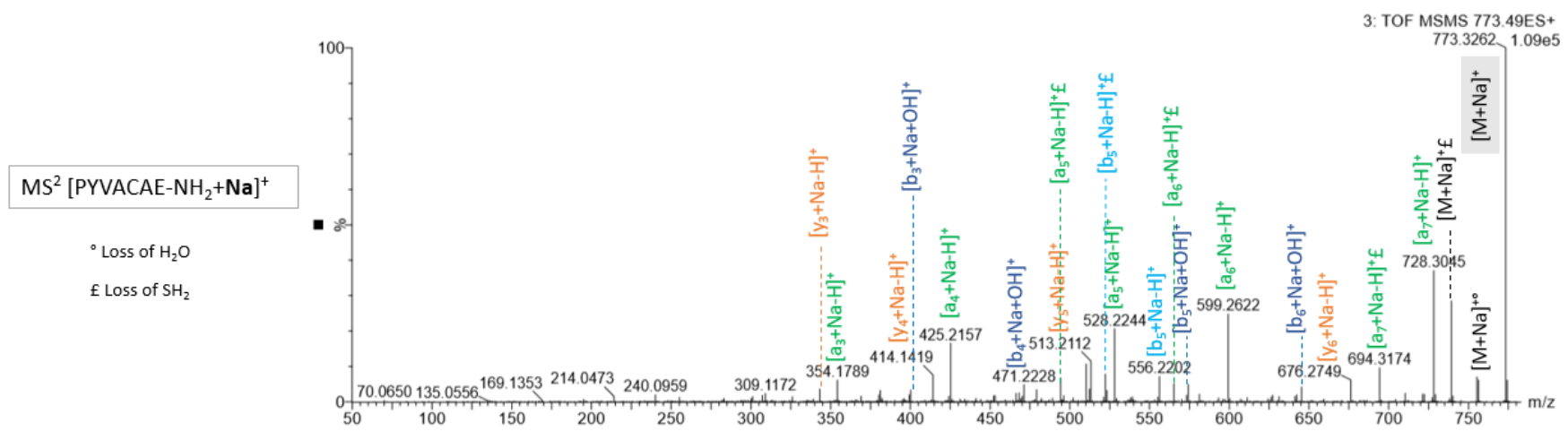

Figure S3d: MS/MS spectra PYVACAE-NH $\mathrm{NH}_{2}$ peptide ( ${ }^{\circ} 16$ in Table 1) recorded on Synapt G2-S mass spectrometer (Q-Tof) 


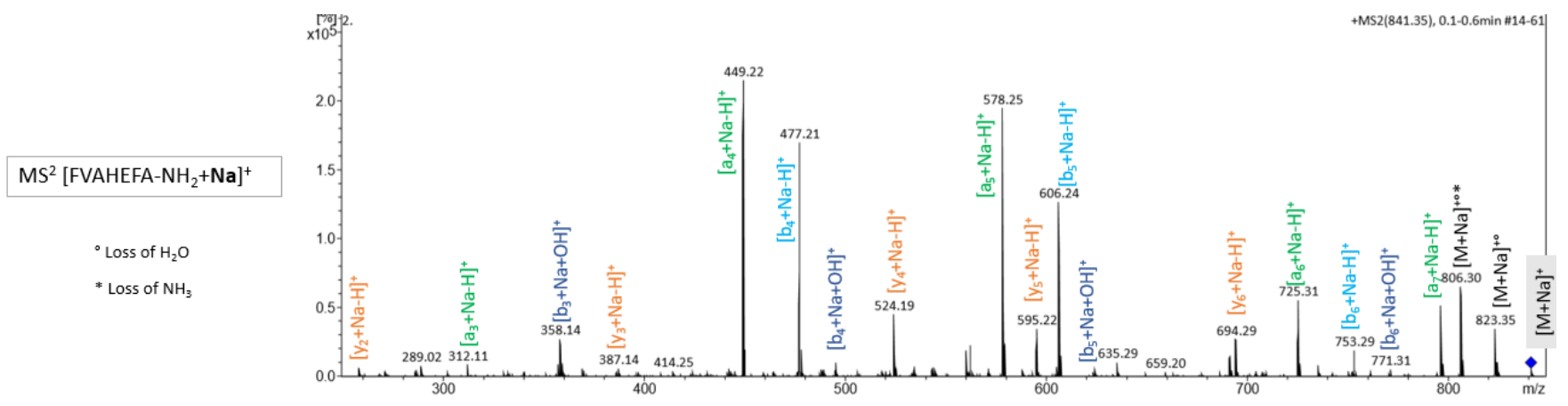

Figure S3e: MS/MS spectra of FVAHEFA- $\mathrm{NH}_{2}$ peptide ( $\mathrm{N}^{\circ} 17$ in Table 1) recorded on Amazon Speed mass spectrometer (Ion Trap)

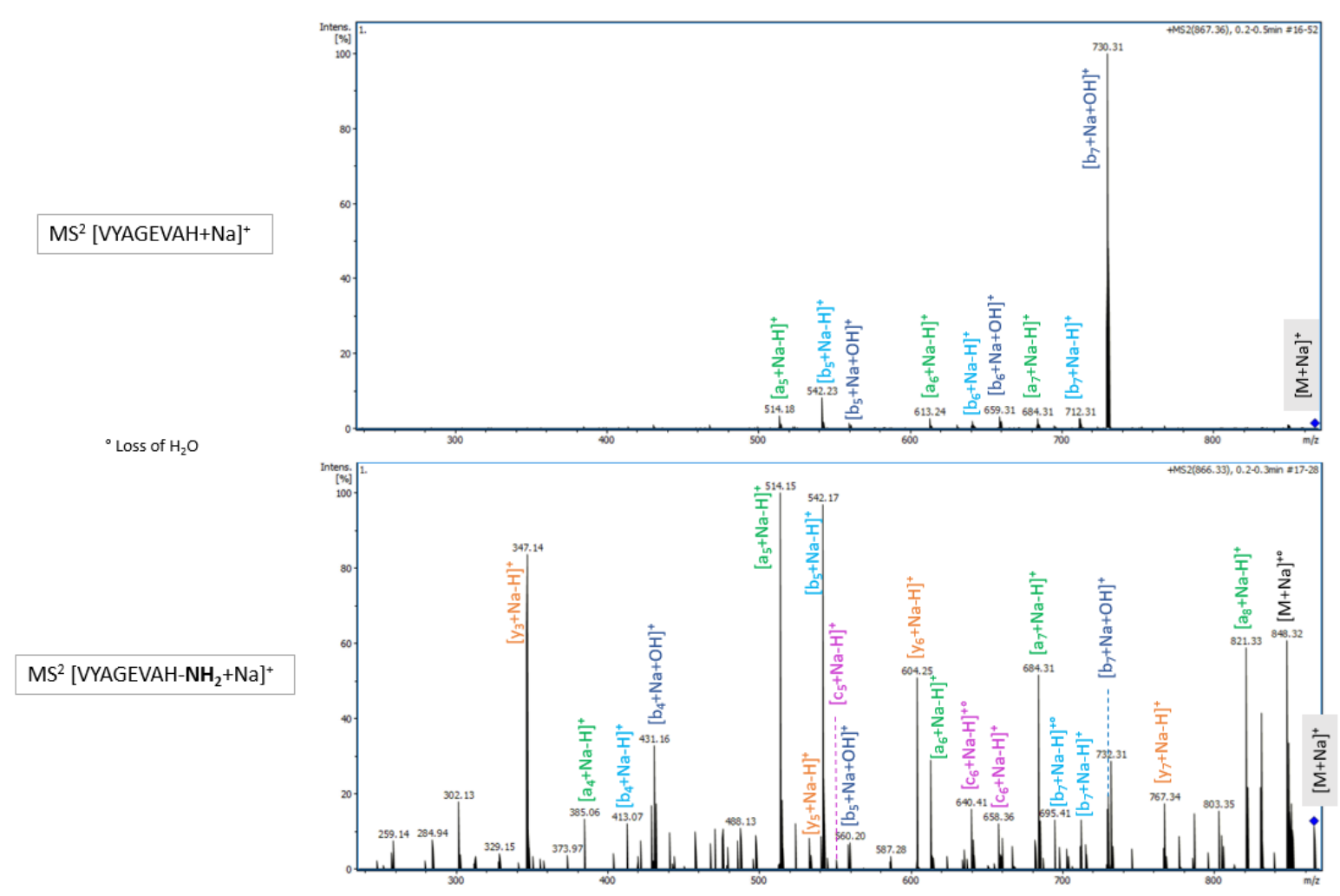

Figure S3f: MS/MS spectra of VYAGEVAH and VYAGEVAH- $\mathrm{NH}_{2}$ peptides ( $\mathrm{N}^{\circ} 18$ in Table 1) recorded on Amazon Speed mass spectrometer (Ion Trap) 
Figure S4: $\mathrm{MS}^{\mathrm{n}}$ iterative experiments from $\left[\mathrm{b}_{6}+\mathrm{Na}+\mathrm{OH}\right]^{+}$ion of FPCEAFA-NH $\mathrm{NH}_{2}$ and FPCEAFA peptides recorded on AmaZon Speed mass spectrometer
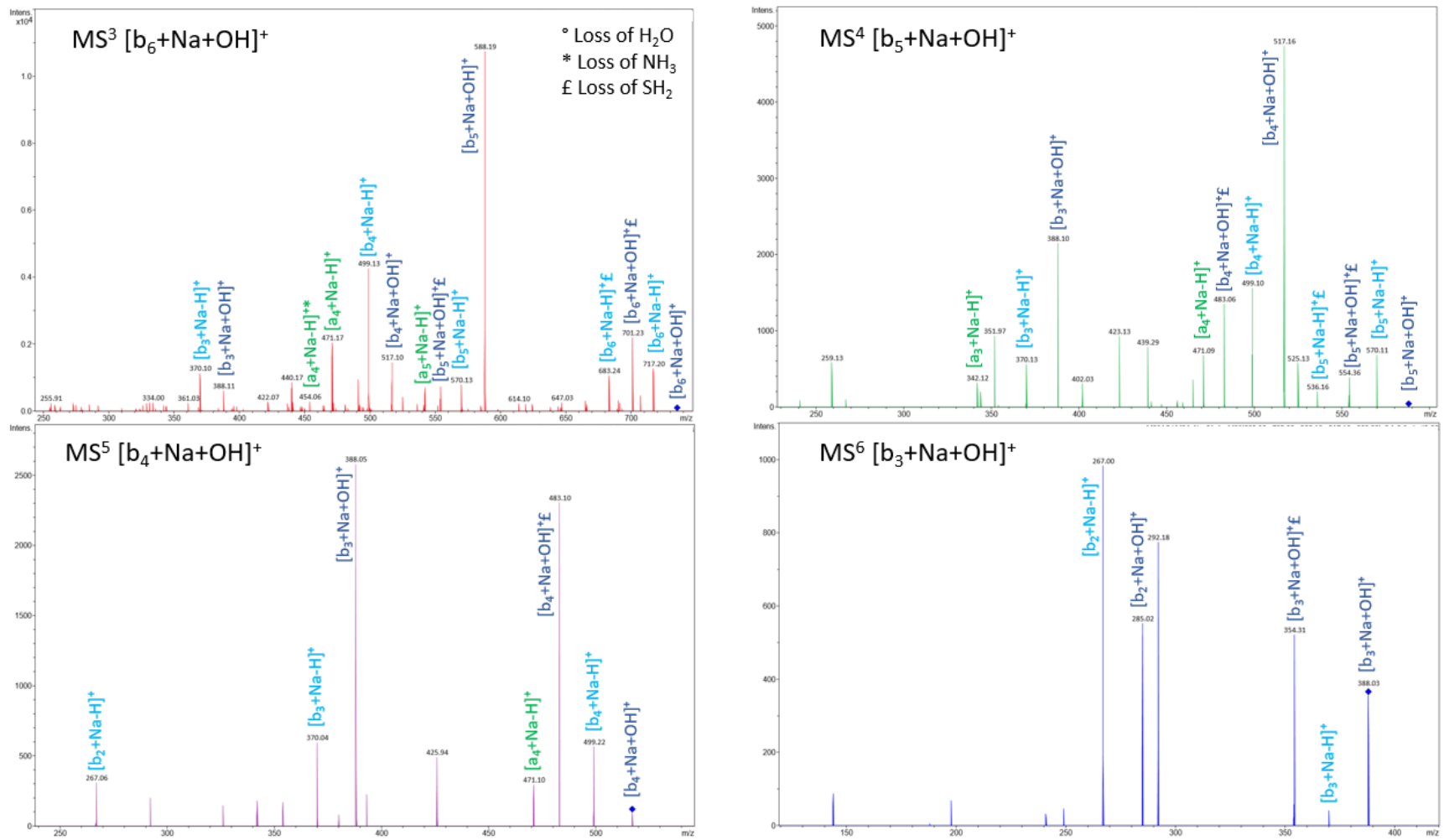

Figure S4a: $\mathrm{MS}^{\mathrm{n}}$ experiment on FPECAFA- $\mathrm{NH}_{2}$ peptide from $\left[\mathrm{b}_{6}+\mathrm{Na}+\mathrm{OH}\right]^{+}$
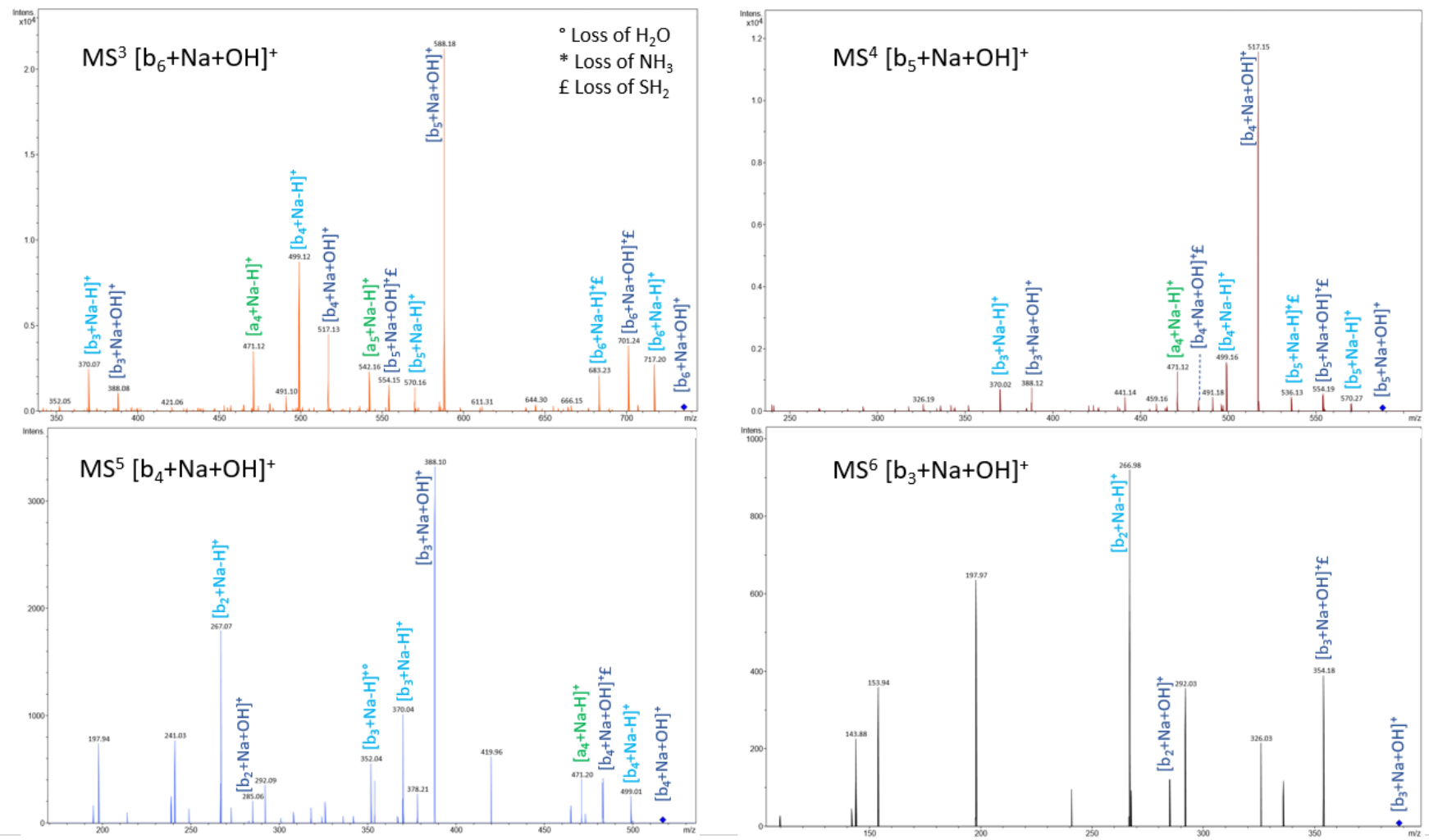

Figure S4b: $\mathrm{MS}^{\mathrm{n}}$ experiment on FPECAFA peptide from $\left[\mathrm{b}_{6}+\mathrm{Na}+\mathrm{OH}\right]^{+}$ 
Figure S5: MS/MS spectra of sodiated Ser-, Thr- or Tyr- containing peptides

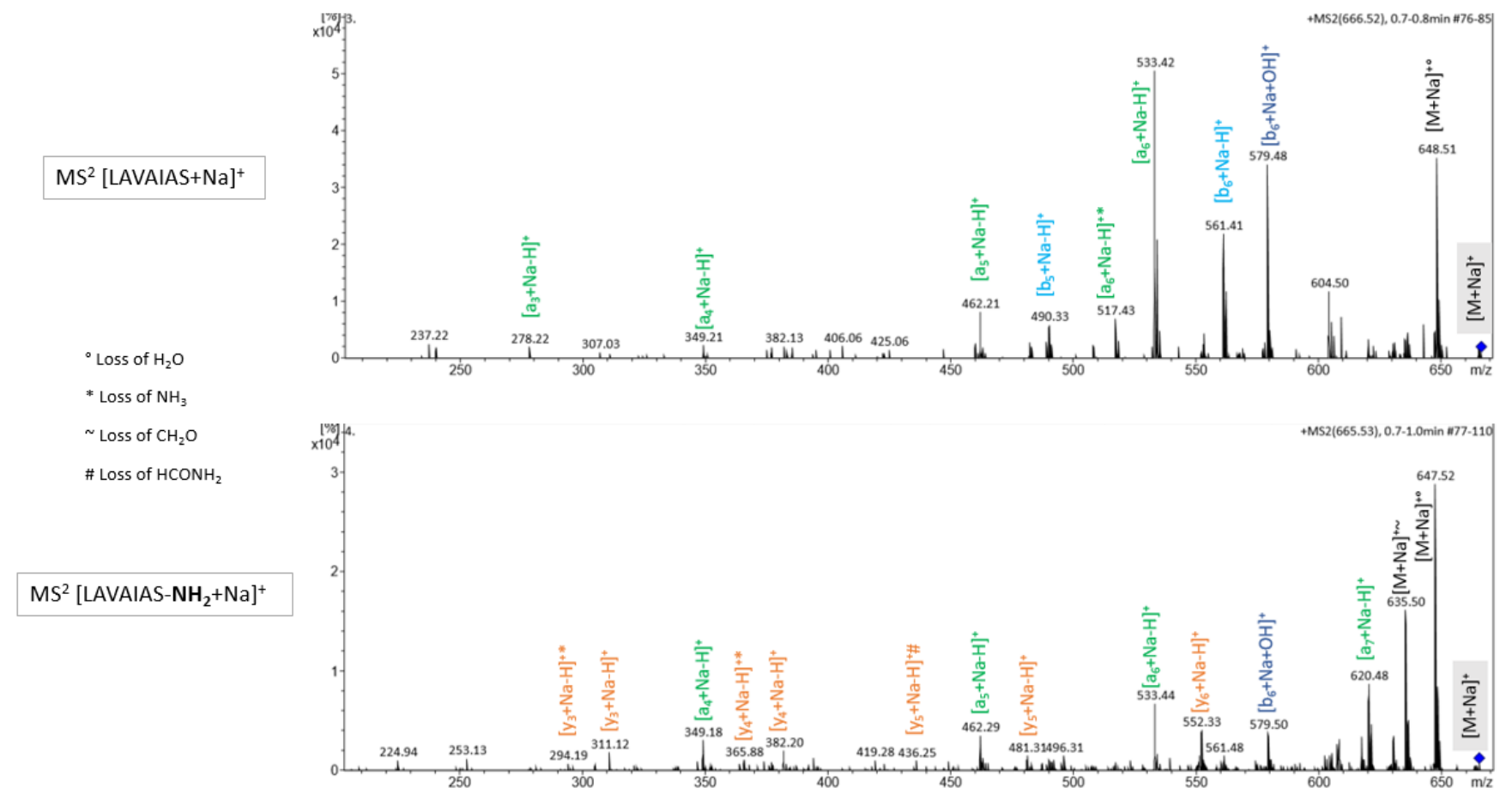

Figure S5a: MS /MS spectra of LAVAIAS and LAVAIAS- $\mathrm{NH}_{2}$ peptides ( $\mathrm{N}^{\circ} 19$ in Table 1) recorded on Amazon Speed mass spectrometer (Ion Trap)

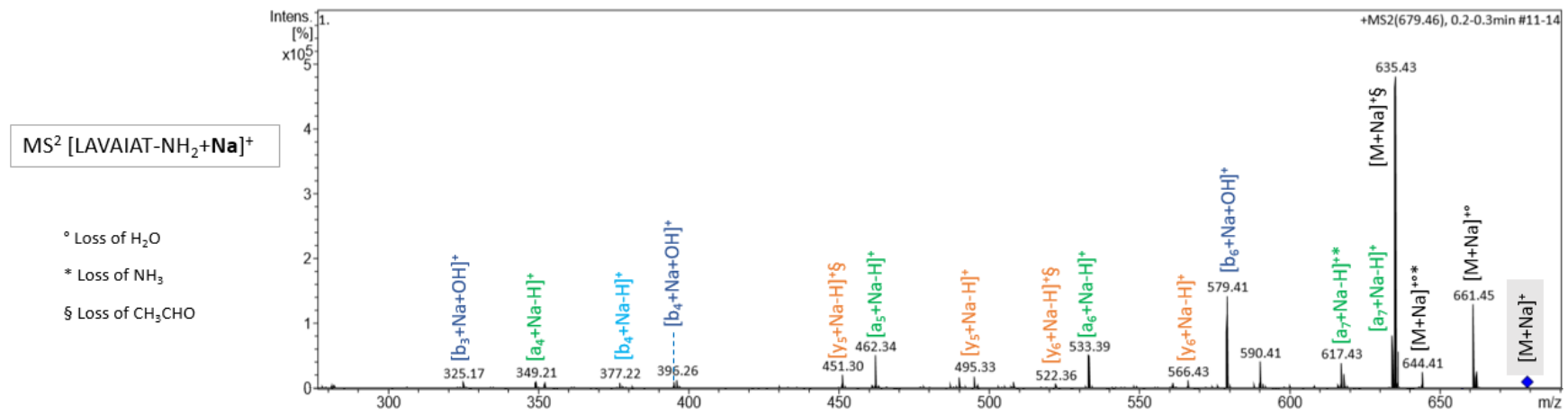

Figure S5b: MS/MS spectra of LAVAIAT- $\mathrm{NH}_{2}$ peptide ( $\mathrm{N}^{\circ} 20$ in Table 1) recorded on Amazon Speed mass spectrometer (Ion Trap)

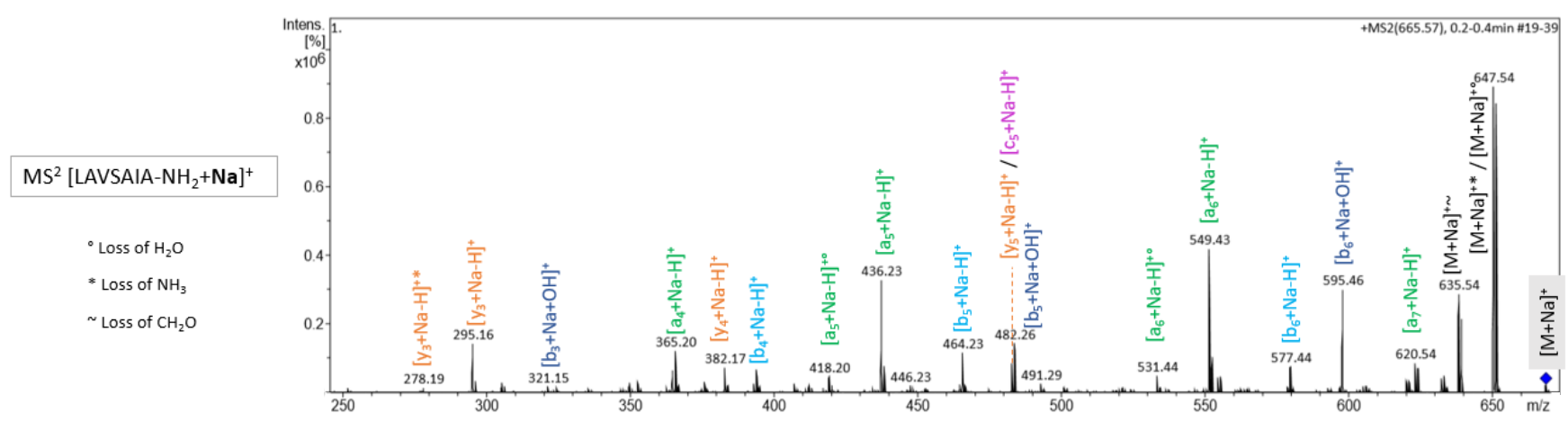




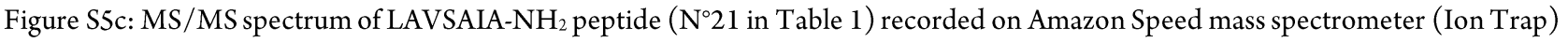

$\mathrm{MS}^{2}[\text { LAVTAIA }+\mathrm{Na}]^{+}$

${ }^{\circ}$ Loss of $\mathrm{H}_{2} \mathrm{O}$ $\S$ Loss of $\mathrm{CH}_{3} \mathrm{CHO}$

$\mathrm{MS}^{2}\left[\text { LAVTAIA- } \mathrm{NH}_{2}+\mathrm{Na}\right]^{+}$

\section{$\mathrm{MS}^{2}$ [SLAVAIA-NH$\left.{ }_{2}+\mathrm{Na}\right]^{+}$}

- Loss of $\mathrm{H}_{2} \mathrm{O}$

* Loss of $\mathrm{NH}_{3}$

$\sim$ Loss of $\mathrm{CH}_{2} \mathrm{O}$ Trap)

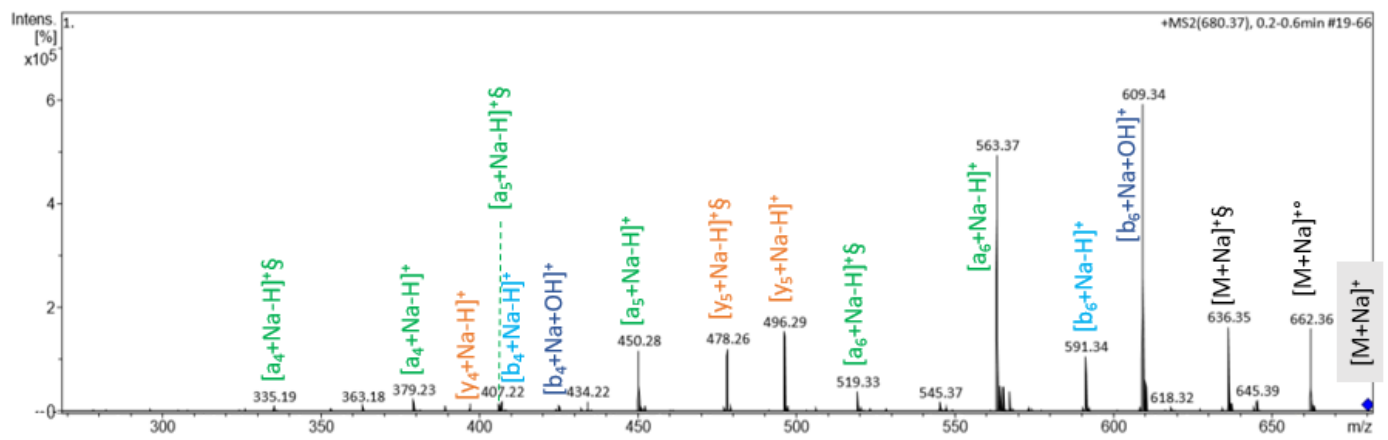

Figure S5d: MS/MS spectra of LAVTAIA and LAVTAIA-NH 2 peptides ( $\mathrm{N}^{\circ} 22$ in Table 1) recorded on Amazon Speed mass spectrometer (Ion

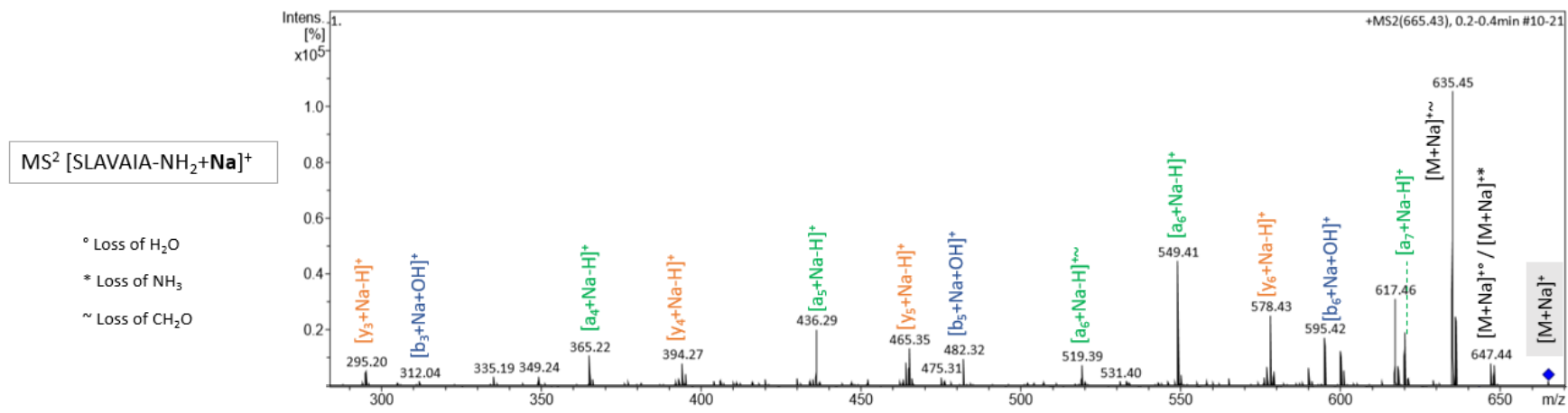

Figure S5e: MS/MS spectra of SLAVAIA-NH $\mathrm{NH}_{2}$ peptide ( ${ }^{\circ} 23$ in Table 1) recorded on Amazon Speed mass spectrometer (Ion Trap)

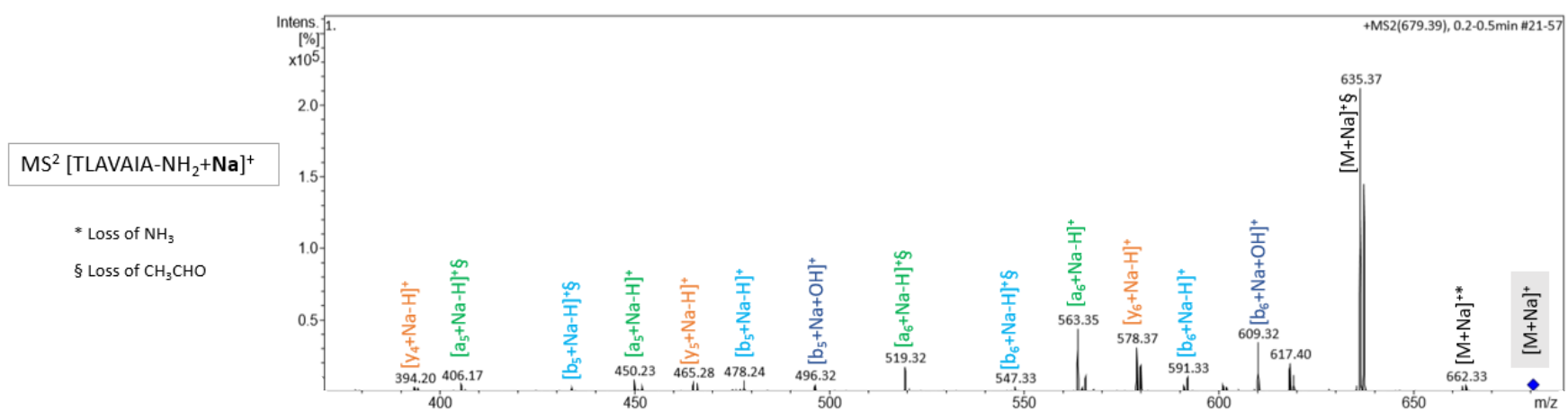

Figure S5f: MS/MS spectra of TLAVAIA-NH 2 peptide (N²4 in Table 1) recorded on Amazon Speed mass spectrometer (Ion Trap) 


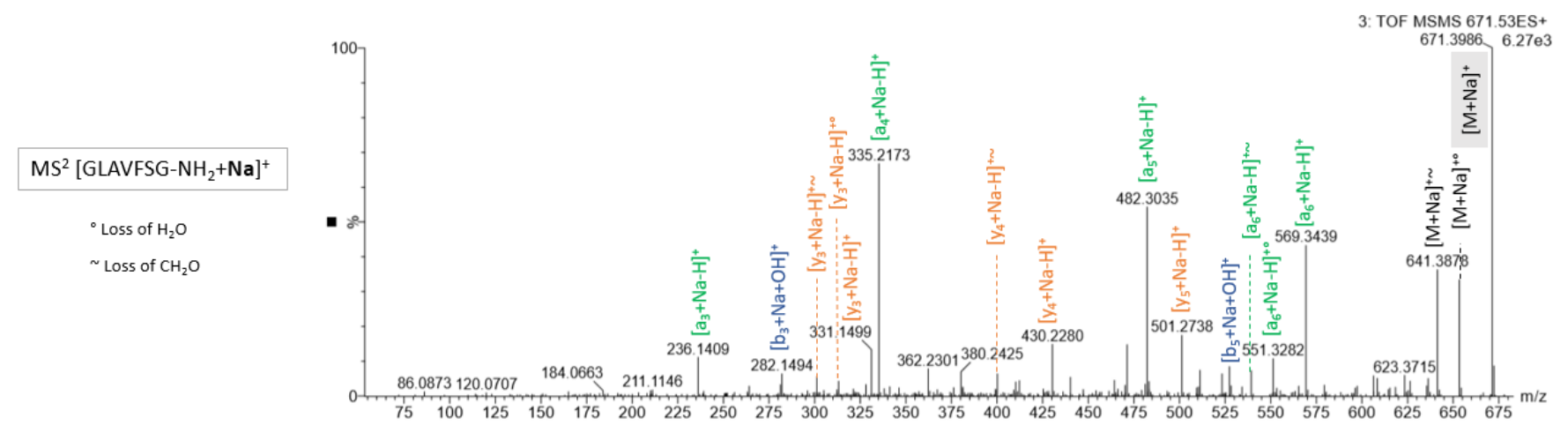

Figure S5g: MS/MS spectra GLAVFSG-NH 2 peptide ( $\mathrm{N}^{\circ} 25$ in Table 1) recorded on Synapt G2-S mass spectrometer (Q-Tof)

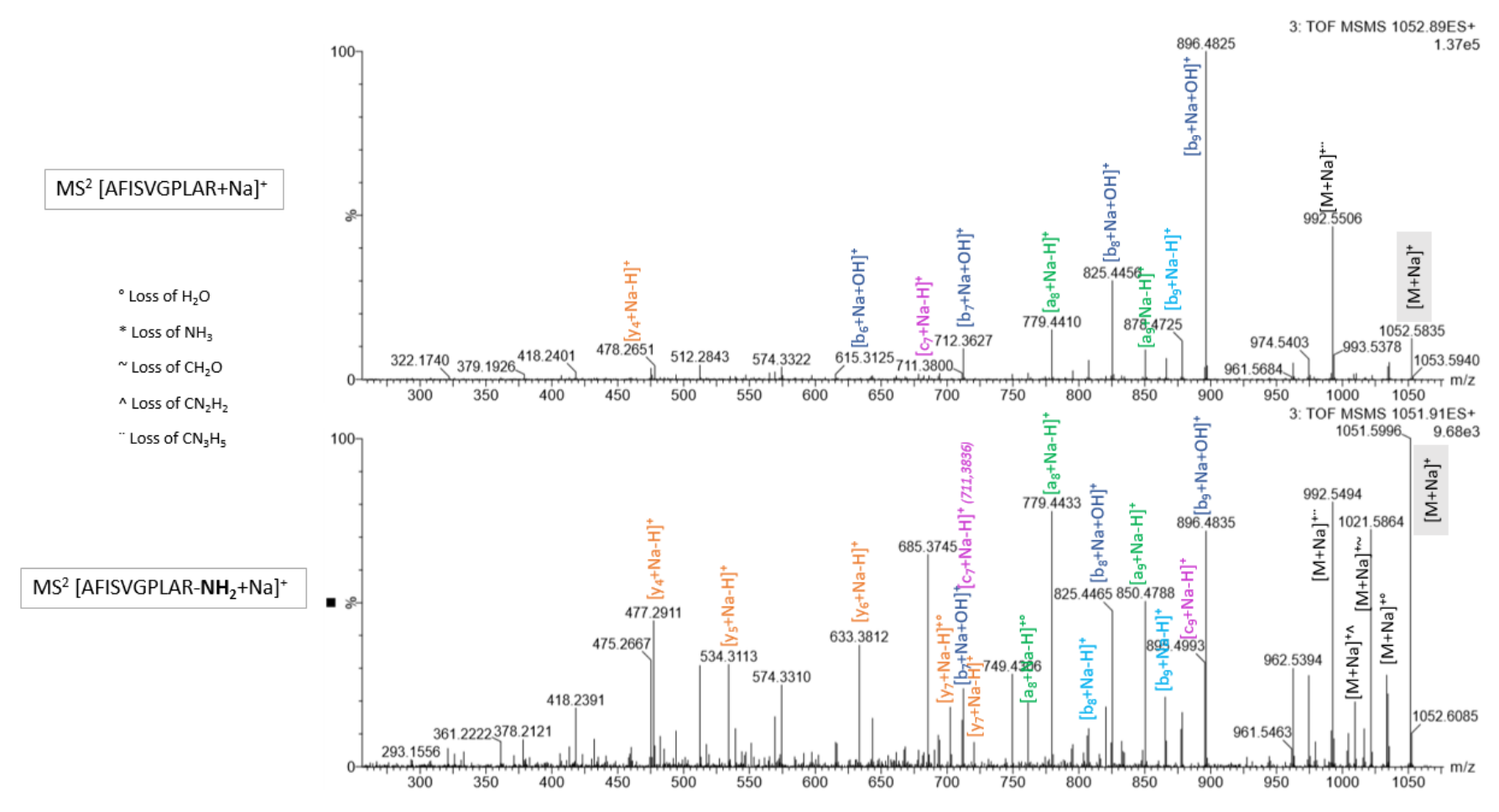

Figure S5h: MS/MS spectra AFISVFGPLAR and AFISVFGPLAR-NH 2 peptides ( $\mathrm{N}^{\circ} 26$ in Table 1) recorded on Synapt G2-S mass spectrometer (Q-Tof)

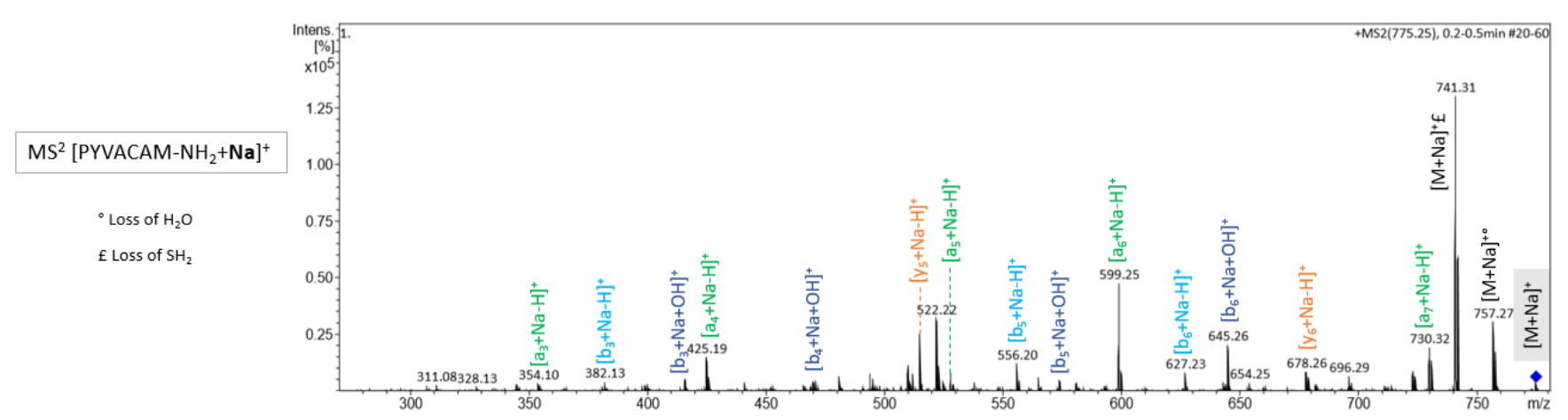

Figure S5i: MS/MS spectra PYVACAM-NH 2 peptide (N²8 in Table 1) recorded on Amazon Speed mass spectrometer (Ion Trap) 


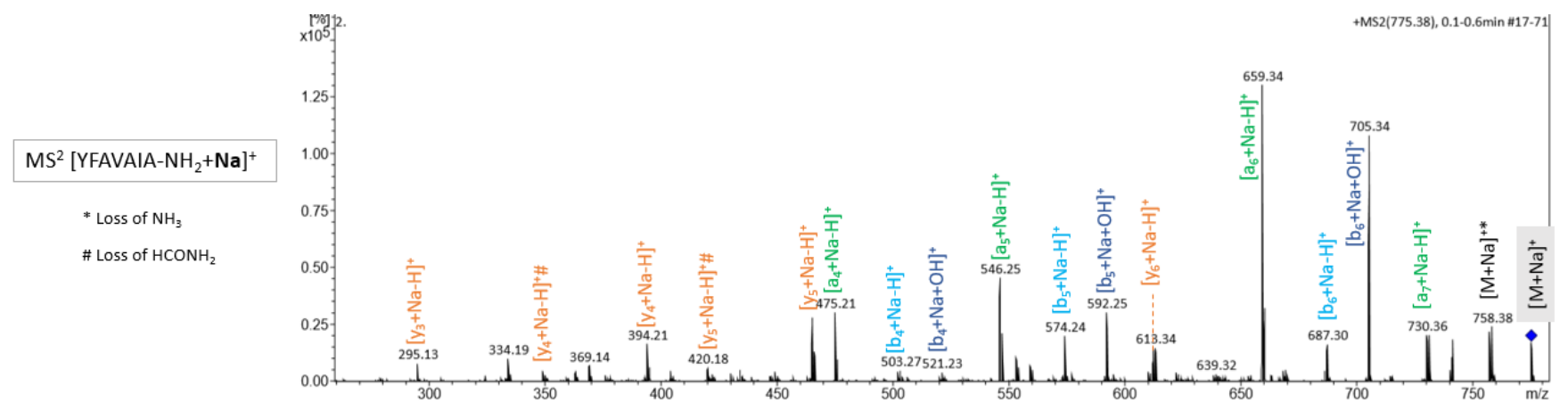

Figure S5j: MS/MS spectra YFAVAIA-NH 2 peptide ( $\mathrm{N}^{\circ} 29$ in Table 1) recorded on Amazon Speed mass spectrometer (Ion Trap)

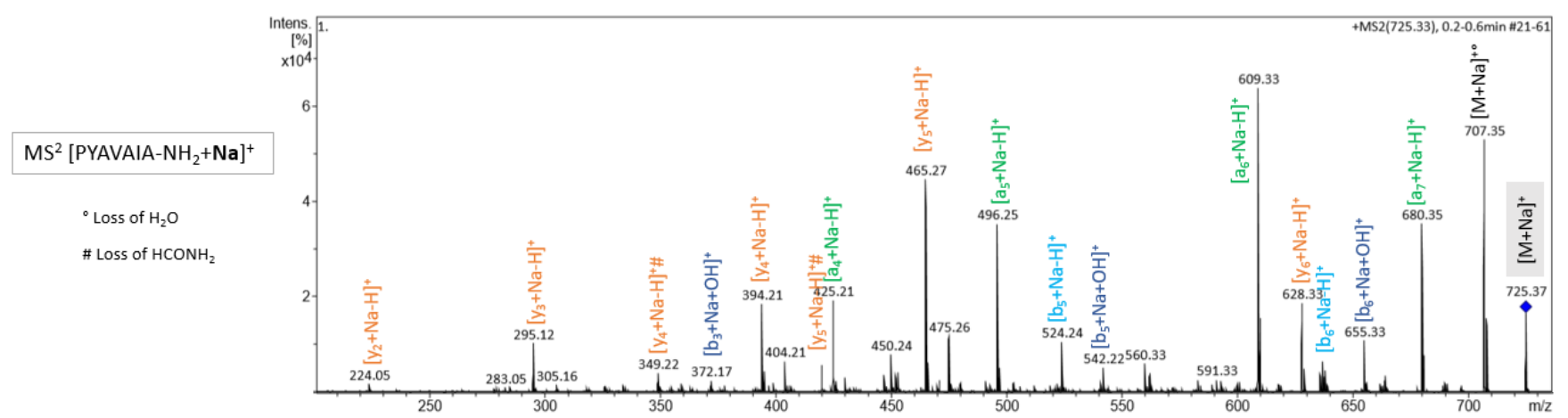

Figure S5k: MS/MS spectra PYAVAIA-NH $\mathrm{NH}_{2}$ peptide ( $\mathrm{N}^{\circ} 27$ in Table 1) recorded on Amazon Speed mass spectrometer (Ion Trap)

Figure S6: $\left[b_{n-x}+\mathrm{Na}+\mathrm{OH}\right]^{+}$ion relative intensities issued from MS/MS experiments of Ser/Thr containing peptides based on SynaptG2S data
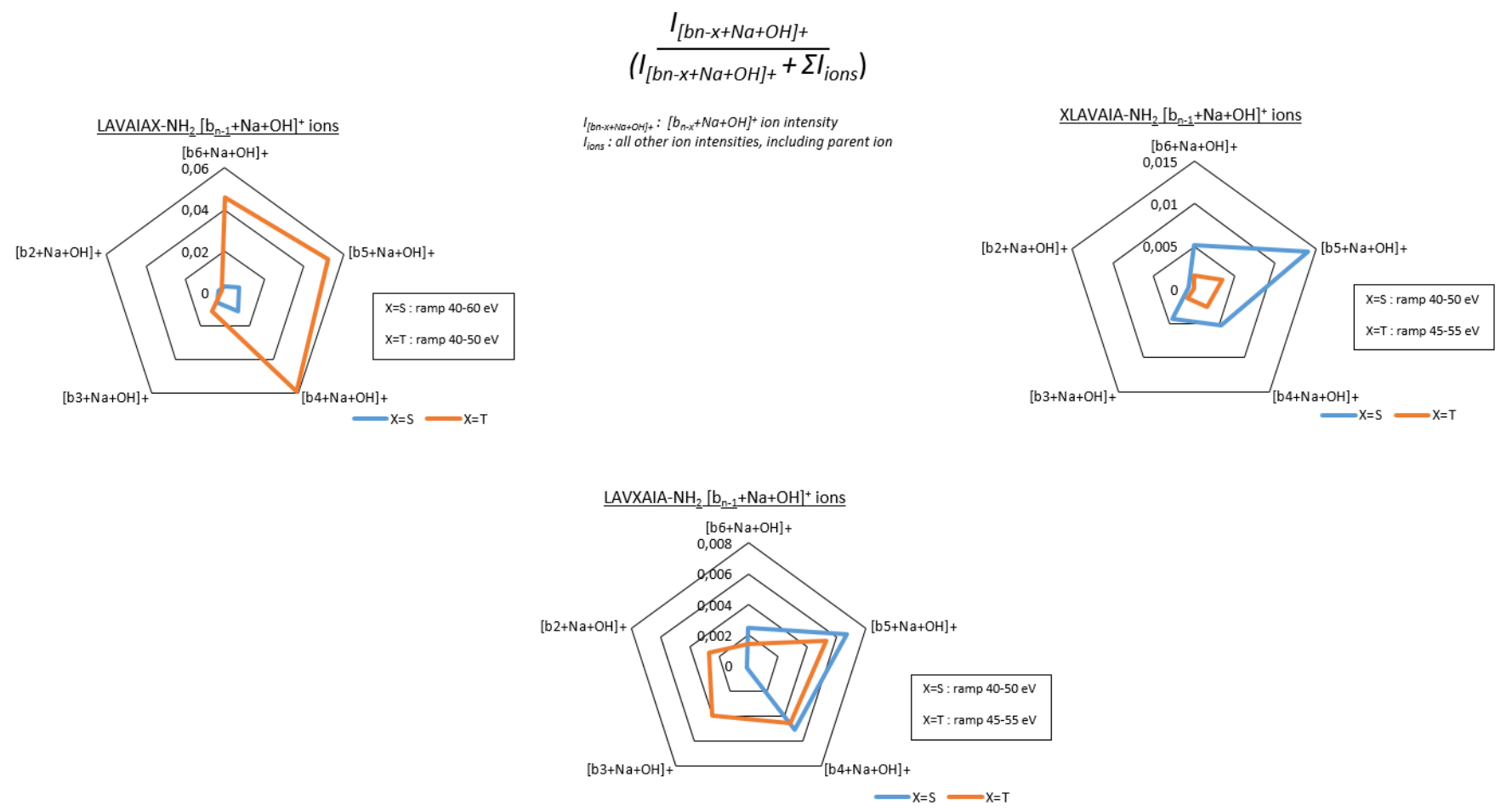
Figure S7: $\mathrm{MS}^{\mathrm{n}}$ iterative experiments from $\left[\mathrm{b}_{6}+\mathrm{Na}+\mathrm{OH}\right]^{+}$ion of YFAVAIA-NH 2 peptide recorded on AmaZon Speed mass spectrometer
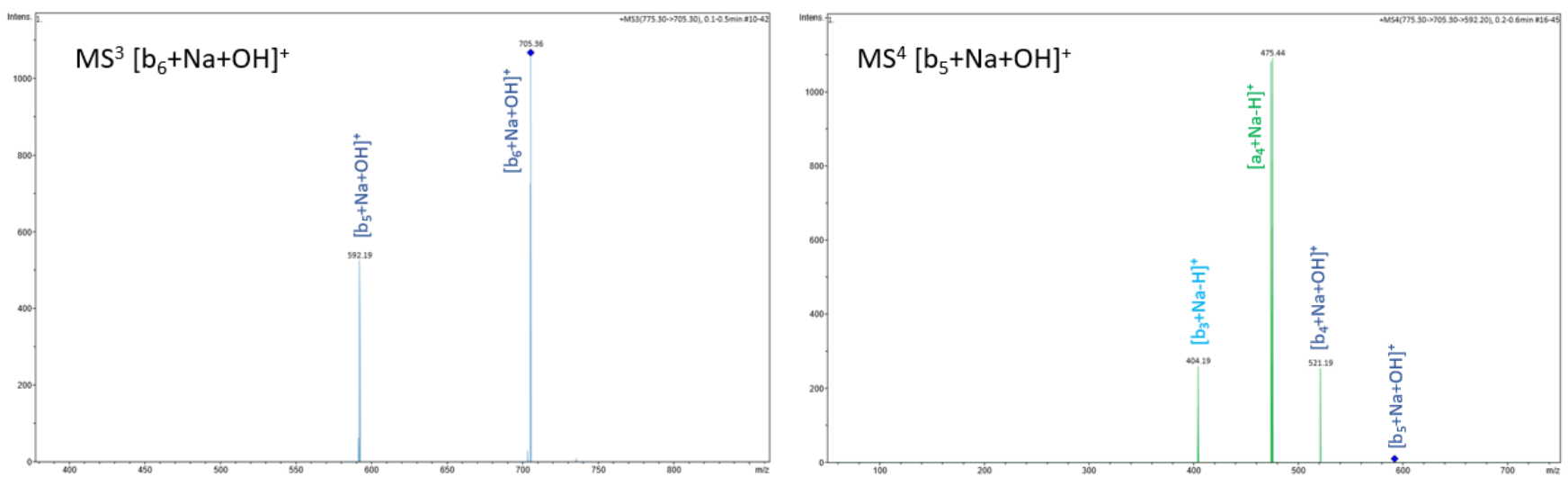

Figure S8: MS/MS spectra of Arg- or His- ended and internal Arg- or His- containing peptides

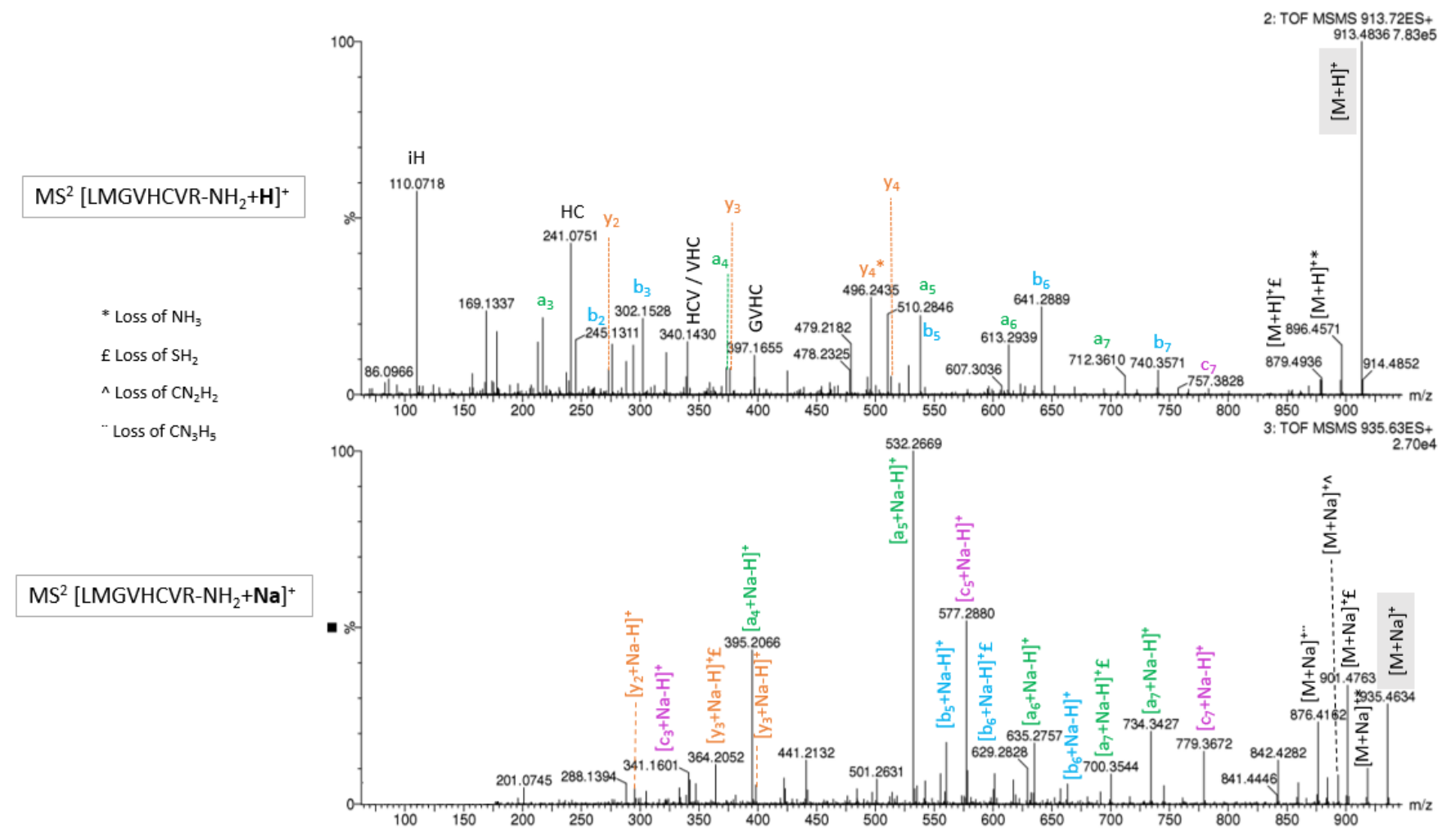

Figure S8a: MS/MS spectra LMGVHCVR-NH2 peptide ( $\mathrm{N}^{\circ} 34$ in Table 1) recorded on Synapt G2-S mass spectrometer (Q-Tof) 


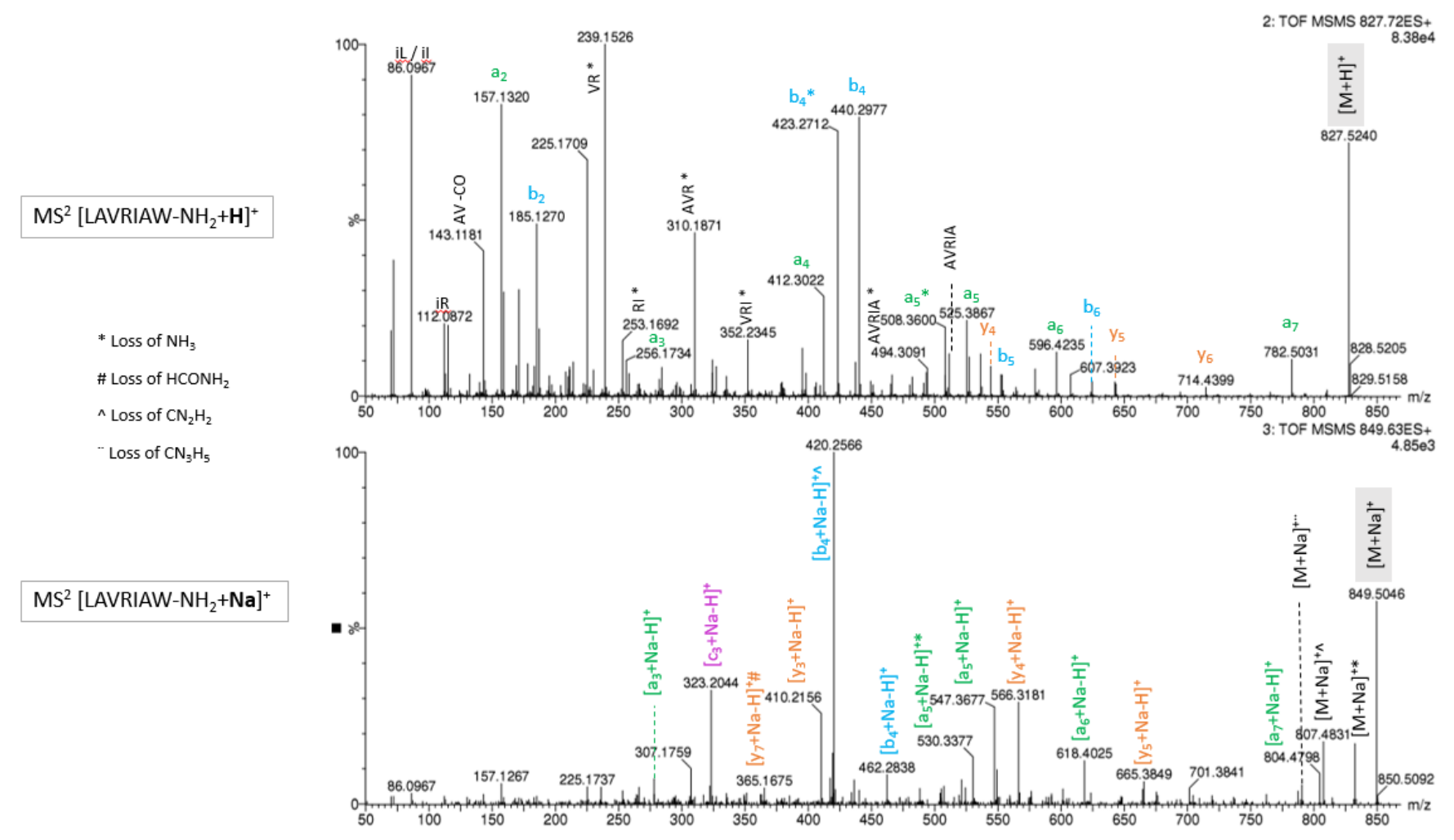

Figure S8b: MS/MS spectra LAVRIAW-NH 2 peptide ( $\mathrm{N}^{\circ} 36$ in Table 1) recorded on Synapt G2-S mass spectrometer (Q-Tof)
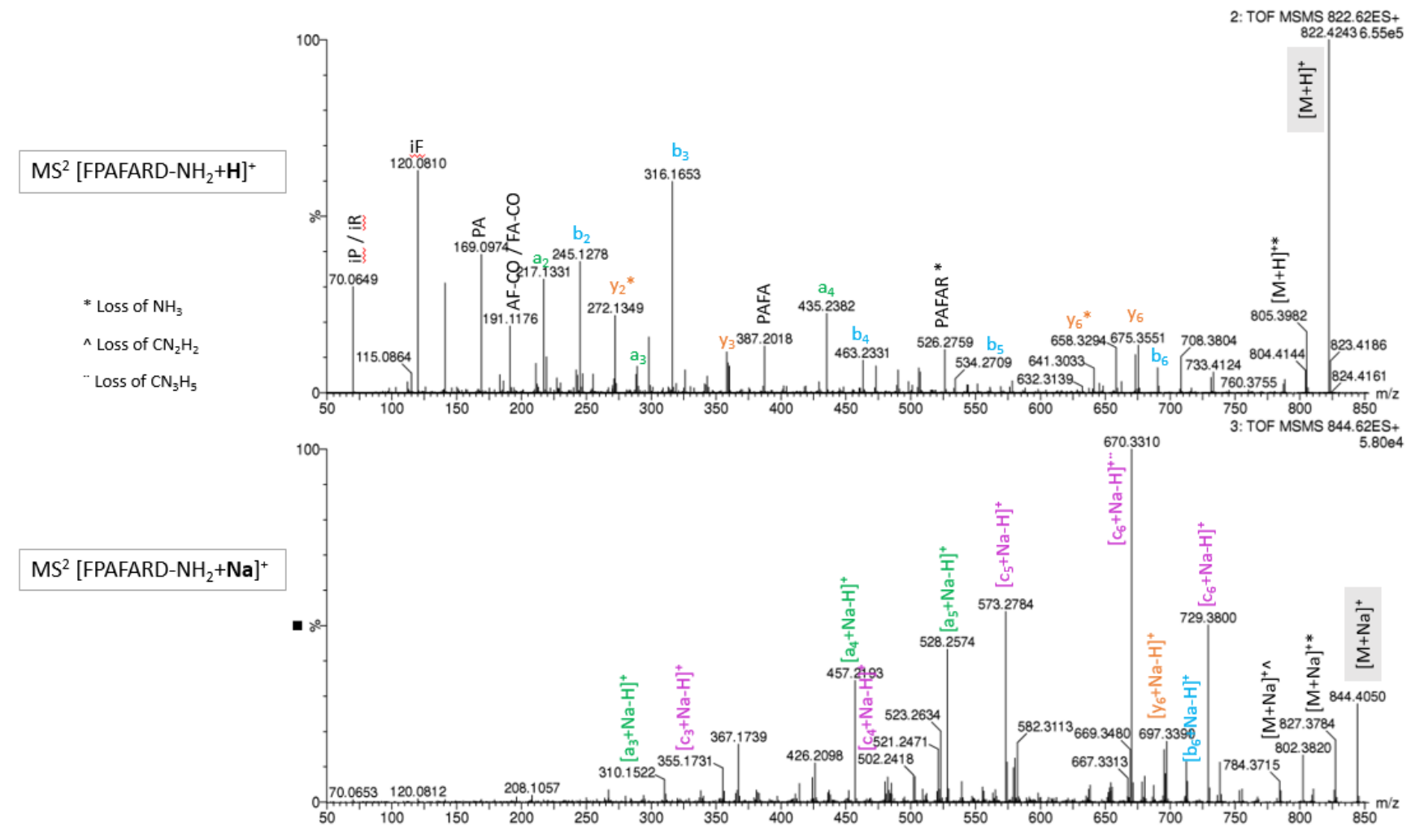

Figure S8c: MS/MS spectra FPAFARD-NH2 peptide (N³8 in Table 1) recorded on Synapt G2-S mass spectrometer (Q-Tof) 


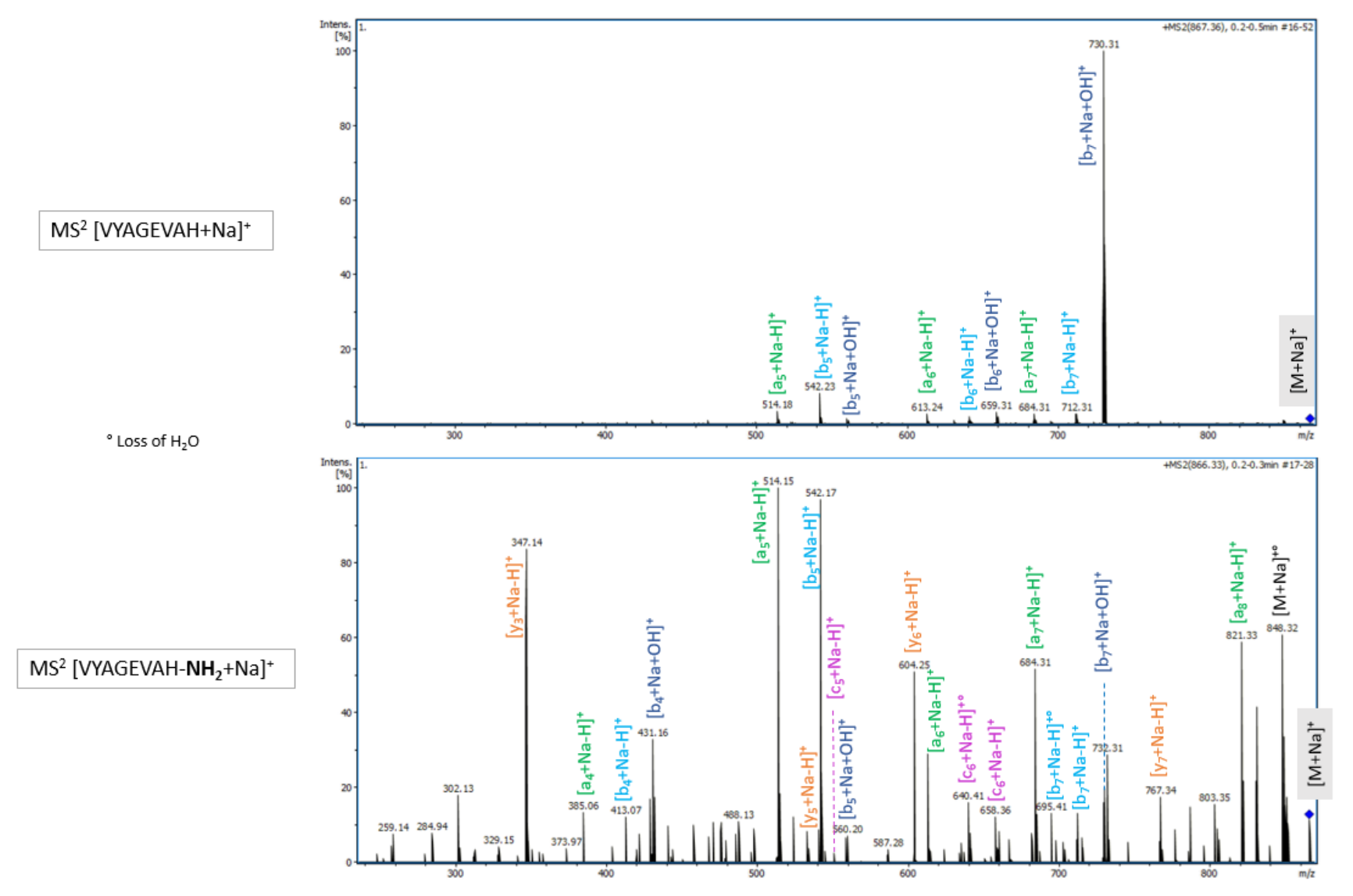

Figure S8d: MS/MS spectra of VYAGEVAH- $\mathrm{NH}_{2}$ peptides ( $\mathrm{N}^{\circ} 18$ in Table 1) recorded on Amazon Speed mass spectrometer (Ion Trap)

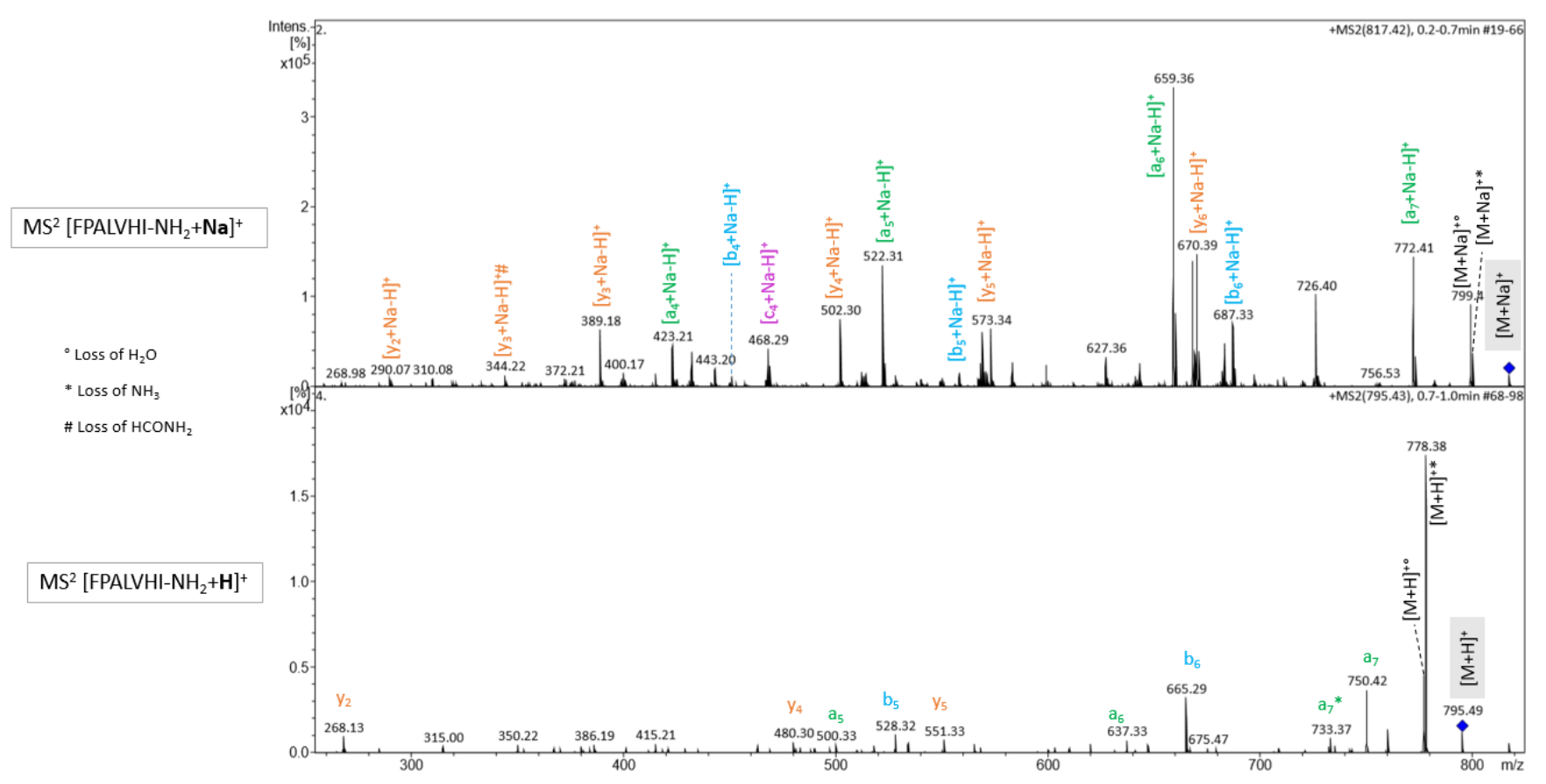

Figure S8e: MS/MS spectra of FPALVHI-NH 2 peptide ( $\mathrm{N}^{\circ} 3$ in Table 1) recorded on Amazon Speed mass spectrometer (Ion Trap) 


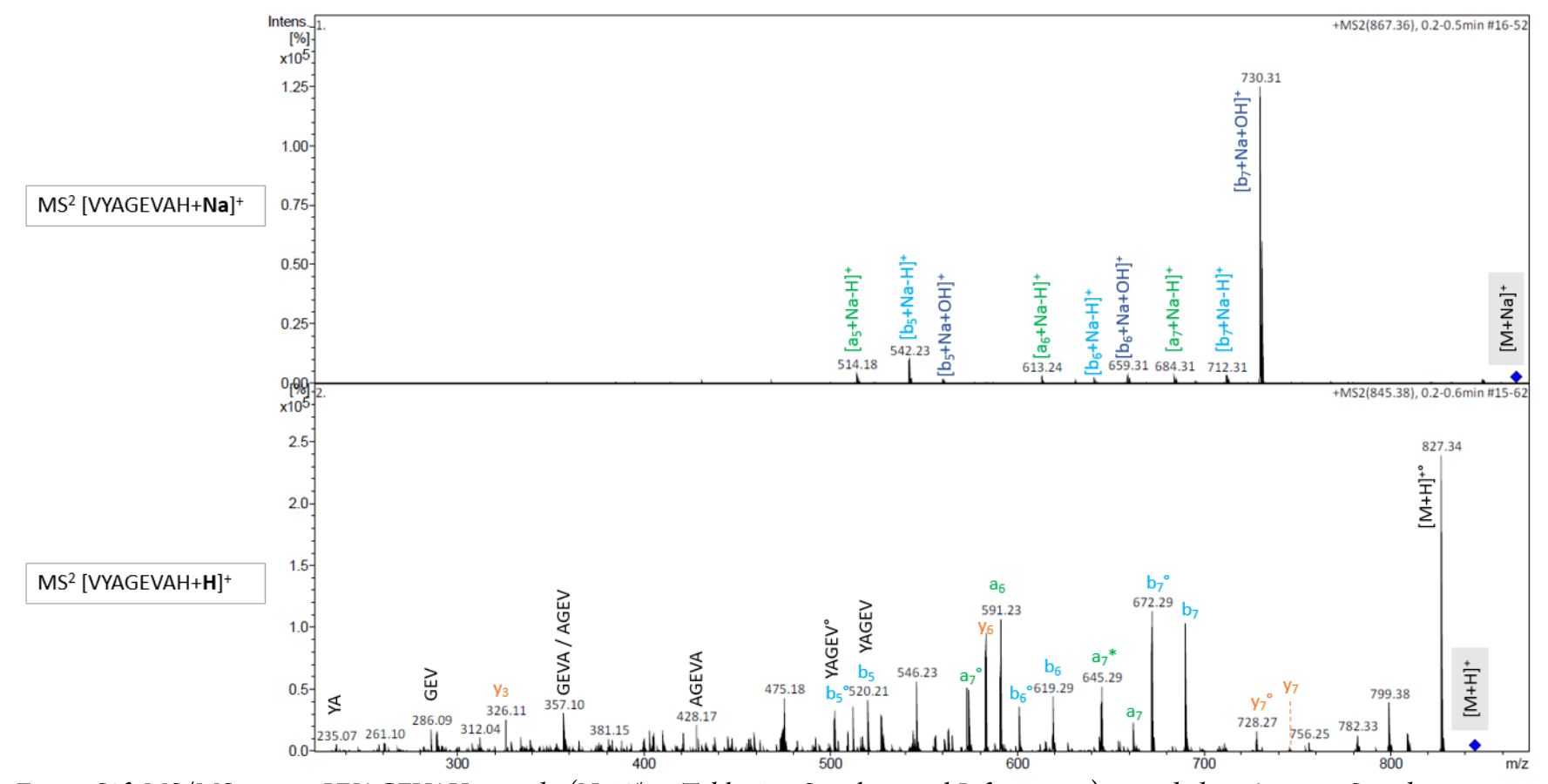

Figure S8f: MS/MS spectra VYAGEVAH peptide ( $\mathrm{N}^{\circ} 18^{*}$ in Table 1 in Supplemental Information) recorded on Amazon Speed mass spectrometer (Ion Trap) 